\title{
Portraits of Deburau in Janin's Deburau, L'Histoire du Théâtre à quatre sous
}

Edward Nye

One of the most famous faces in nineteenth-century French theatre was arguably that of JeanGaspard Deburau, the Franco-Bohemian Pierrot actor who performed at the Théâtre des Funambules in Paris from 1816 until his death from tuberculosis in 1846. His fame derived doubtless from his talents as a resolutely silent mime, but also from the efforts of a number of high-profile writers, critics, and fine artists to promote him as a representative of certain artistic and socio-political values. A combination of his talents and their promotion produced an image and persona which persisted after his death and is still with us today: the whitefaced Pierrot wearing his black skullcap and voluminous white costume, miming in complete silence. Before Deburau and his promoters, Pierrot did not look or behave quite like this, nor did he achieve quite the same level of fame. ${ }^{1}$ The very success and ubiquity of this image might lead spectators and scholars to take it for granted, to neglect its interpretation, because it has essentially become a cliché. There is, however, a great deal more to this cliché than one might think.

In this article, I consider the illustrations provided by a number of artists and engravers for the most well-known contemporary text on Deburau, Jules Janin’s Deburau, L'Histoire du théâtre à quatre sous (Paris: C. Gosselin, 1832). This book is a biography of Deburau written much in the manner of Sainte-Beuve's literary 'portraits,' a biography reliant as much on the intuitions and imagination of the author as on the verifiable facts of the subject's life. The artists who illustrated it obviously responded to Janin’s biographical approach. Their illustrations demonstrate a close intermedial relationship with Janin's text, 
sometimes working in parallel to encourage the reader-viewer towards a similar interpretation of Deburau, sometimes apparently at variance with it in order, overall, to increase the impact of certain ideas about the mime-actor.

\section{Pierrot at the balustrade}

Deburau must have been well known to the spectators of the Théâtre des Funambules throughout the $1820 \mathrm{~s},{ }^{2}$ but he came to wider prominence in 1828 when a number of flattering newspaper articles appeared, notably that by Charles Nodier in La Pandore. ${ }^{3}$ Janin’s monograph four years later was the first extended contemporary piece of writing on Deburau, and it contains the greatest number of images of him of any text produced in his lifetime, with one exception. ${ }^{4}$ It opens with Bouquet’s frontispiece, engraved by Henri-Désiré Porret, which I will refer to as "Pierrot at the balustrade" (Figure 1). [Figure 1 near here] It is one of many contemporary copies or imitations of the portrait in oils of Deburau (no longer extant) that Bouquet exhibited at the 1831 Paris Salon. ${ }^{5}$ It shares enough of the features of these other imitations to suggest that it is relatively faithful to Bouquet's original.

"Pierrot at the balustrade" is an unusual kind of portrait. Since the mid-eighteenth century when portraits of actors became widespread in France, they were almost always of two kinds: either they showed the actor in character, perhaps even on stage amidst the action of a play (sometimes a specific character in a specific play), or the actor was represented as a private citizen in everyday dress. ${ }^{6}$ There are only partial exceptions to these conventions, partial cases of an overlap between the representation of the actor in character and the representation of the private person. One such exception might be those portraits showing actors in costume returning the gaze of the viewer; they are dressed for the stage but not acting, but the potential contrast is weakened by the fact that there is no backdrop to the figure, no stage or scenery. ${ }^{7}$ These portraits are so abstracted from their theatrical context that 
they look like costume designs as much as portraits of specific actors. Another potential site for ambiguity between the actor and the stage character is to be found in portraits of actors in everyday dress which are accompanied by a small vignette showing a scene from one of their plays. In reality, however, there is no ambiguity; these works would be best described as twin or double portraiture, as two separate, if contiguous representations showing the same person in different contexts. ${ }^{8}$

In contrast to the prevalent conventions, the "Pierrot at the balustrade" portrait encourages the viewer to confuse the private individual with the Pierrot role: Deburau is in costume on stage and leaning on what appears to be stage scenery, inviting us to think we are seeing Pierrot. Yet there is no action and he stares back at us, breaking the theatrical 'fourth wall,' as if he were not acting, as if he were not Pierrot but Deburau, the private individual. One might be tempted to think this is a reflection of Deburau's stage persona, that he had a tendency to acknowledge, metatheatrically, the presence of the audience, as his erstwhile Théâtre des Funambules co-actor Frédérick Lemaître famously did in L'Auberge des Adrets. ${ }^{9}$ Or perhaps his typical behavior on stage was to be a passive spectator of the action. There is scarcely any evidence for either of these interpretations. ${ }^{10}$ Alternatively, one might be tempted to attribute this kind of ambiguous portrait to Pierrot's background in the Comédieitalienne and Commedia dell'arte traditions in which a successful actor regularly performing one of the tipi fissi might easily become closely associated with the role. A consequence of this might be that a portrait of Deburau is inevitably a portrait of Pierrot. Even though there would be a certain logic to this interpretation, in practice there are no portraits of Comédieitalienne or Commedia dell'arte roles like "Pierrot at the balustrade.” Instead, they follow the conventional dichotomy between representation of actors as private individuals, and representations in character or in role. ${ }^{11}$ 
The desire by the portraitist to distinguish between the private individual and the stage role is indicative of a fundamental aspect of portrait painting, almost its reason for being, which is that it should have a clear referent. The subject has to be recognizable, it has to be a portrait of someone (even if that someone is anonymous). In the case of the "Pierrot at the balustrade,” the referent is not clear: does the viewer see the real Deburau, the actor who happens to be wearing his costume, or does he see the fictional role of Pierrot? "Pierrot at the balustrade” breaks the contemporary conventions. One might think of it as a portrait of an actor taking a break from rehearsals, an 'occupational portrait' of the kind later developed by Courbet, Manet, and Degas who focused on milieu as a way of conveying personality.

Although this portrait is scarcely comparable to paintings or engravings by other contemporary artists, it is reminiscent of portraits in words most notably by Sainte-Beuve. His form of literary criticism based on biographical study of the artist is akin to the way Bouquet encourages the viewer to associate Deburau with his stage persona. Sainte-Beuve’s approach probably resembles Bouquet's in another way: they both allow their personal intuitions or imagination to guide their representation of what they think is the 'spirit' of the portrayed subject, making what one might call, after Baudelaire, a 'fictional' rather than a 'historical' portrait. ${ }^{12}$ It is impossible to know for sure, in the absence of Bouquet's original oil painting and photographs of Deburau, but the drooping eyes and eyebrows in this frontispiece are probably an addition for the purposes of Janin's book. Most images of Deburau do not represent him like this, and most copies of Bouquet's original oil painting do not. The effect in the frontispiece is to imply a certain plaintive or sentimental aspect to Deburau's Pierrot role. Yet there is no evidence that Deburau played the role in a sentimental manner at all; as his biographer has put it, the "sel forain" of his style was quite unlike the "sucre vanillé" of sentimental Pierrots. ${ }^{13}$ This plaintive facial expression suits perfectly, however, the way Janin represents Deburau in the text of his book as a suffering artist. For example, Janin clearly 
revels in recounting the probably apocryphal story of Deburau taking the theatre manager, Bertrand, to court over the humid conditions of his dressing room, presenting an enormous mushroom as evidence (Janin vol. 2, 170). The mushroom was as likely to have been a figment of Janin's imagination as the plaintive expression on Deburau's face was for Bouquet. Both Bouquet’s and Janin produce ‘portraits’ which involve a good deal of the subjective intuition, presumably because like Sainte-Beuve, they considered it essential to 'poetic' biography and a renewal of literary or artistic criticism. As much as they manifest a certain 'portraitomania,' therefore, their zeal is not gratuitous.

One ought to interpret the backdrop to this portrait in the same manner. Bouquet's version for the frontispiece is the only one to consist of pine forests and a castle atop a mountain. Every other version (and probably, therefore, Bouquet's original painting) has an Arcadian landscape of sculptural trees, an expanse of sky and probably a lake, all of which are reminiscent of the seventeenth-century landscapes of Claude Gellée ('Claude Lorrain’) or the eighteenth-century landscapes of Watteau. The different landscape in the frontispiece of Janin’s book seems intended to denote Deburau’s geographical origins in Bohemia. In itself, this is a verifiable fact, but in Janin’s text, it becomes something else. Janin portrays Deburau as 'Bohemian' in both senses of the word: born in Bohemia, but also a fiercely creative and non-conformist artistic genius who rejects the status quo by intentionally occupying the fringes of artistic society (the Théâtre des Funambules was the cheapest and by many accounts the most insalubrious theatre in Paris). It is precisely in this period, the 1830s, that 'Bohémien' starts to acquire this sense, rather than meaning simply a native of the Kingdom of Bohemia, or else a petty criminal. There is nothing to suggest, in reality, that Deburau deserved this image of the Bohemian artist. Janin is almost certainly inventing it. Like the sentimentality, it is a demonstration of why the portrait format appealed so much to artists, 
writers, and their viewers and readers: it was a way to explore intuitive insights into what Baudelaire called the subject’s “spirit” (467).

If there is something in "Pierrot at the balustrade" which is reminiscent of Watteau's Pierrot (1718-1719) then this is no coincidence. It is at about this time, during the 1830s, that Watteau's painting starts to provoke new interpretations and questions which have persisted to this day: the sad or melancholy clown, the suffering artist, the innocence symbolized by the whiteness, the general mystery of who Watteau's Pierrot is looking at, where he has come from and where he is going, and the apparent "semantic vacuum” in the painting. ${ }^{14}$ The painting had never provoked these issues before. In fact, eighteenth- and early nineteenthcentury critics had hardly considered the portrait worthy of comment or attention at all. It was Romantic critics such as Emile Deroy who attributed great significance to it. ${ }^{15}$ Modern scholarship is skeptical of his interpretation and others which do not take into consideration a likely reason why the painting was commissioned: as a street sign for a famous Pierrot actor, Belloni, when he retired from the stage and opened an inn. This may be why Watteau made this canvas his largest (184 cm by $149 \mathrm{~cm}$ ), and why he gave Pierrot such a simple, inexpressive pose: the portrait was intended to be clear and visible in a bustling street context. ${ }^{16}$ Although the intended use of the two portraits by Watteau and Bouquet was different, the new interpretation of Watteau's painting in the 1830s is analogous to the interpretation of Bouquet’s portrait that Janin’s text encourages. Even if Bouquet had not drawn Deburau with Janin's vision of the actor in mind, the reader of Janin's book can hardly avoid seeing the portrait through the lens of Janin’s biography.

\section{Pierrot the cobbler}

The next of Bouquet's portraits, engraved by Cherrier, comes only three pages later and contrasts quite markedly with "Pierrot at the balustrade." It shows Deburau playing the part of 
a "Savetier," or cobbler, but still visibly in the role of Pierrot with his white face makeup (Figure 2). ${ }^{17}$ [Figure 2 near here] Without Janin's text, one would conclude that this a fairly straightforward portrait of Deburau acting a part (albeit with the unusual feature, again, of looking back at the viewer), and doing so comically with an odd hat set at an unlikely angle and a mouth contorted in the same direction as the thread he is pulling. Indeed, readers who were also spectators at the Théâtre des Funambules would have recognized the image as that of Deburau playing Jacquot in Le Lutin femelle, pantomime dialoguée en trois actes, performed the year Janin published his book, $1832 .{ }^{18}$ At first glance, there is no serious substance to this image; it is comic and characterful. When considered in the light of Janin's text, however, the image is more provocative. Janin makes much of Deburau as a workingclass artist, the equivalent of the “ouvriers-poètes” promoted by George Sand, Charles Nodier, and others: an artist from a working-class background who produces art inspired by that background. As such, Deburau is, for Janin, a figurehead of the working class as well as a leading light in purely artistic terms. This is part of the reason for the portrait 'mania' in the period: socio-political movements need figureheads, portraits that inspire, that encapsulate ideas and concepts. Janin writes very clearly and succinctly what Deburau encapsulates: he is the 'people’s Pierrot,' “Gilles, c’est le peuple” (Janin vol. 1, 112; 'Gilles’ and 'Pierrot' were synonymous in this period). That the working class should have its own form of entertainment was not controversial. Janin, however, supposes that this form of working-class entertainment is in fact the highest form of contemporary theatre, and indeed the future of theatre: "il n'y a plus de Théâtre-français, il n’y a plus que les Funambules” (Janin vol. 1, 12). He spells out the consequences in his characteristically graphic manner:

Aujourd'hui l'art dramatique mange des pommes de terre frites sur le boulevard du Temple, il raccomode ses bas troués à la porte de son théâtre, il s’enivre chez le 
marchand de vin, il avait du fard autrefois, il a de la farine à présent. Autrefois il s’appelait Molé ou Talma, aujourd’hui il s’appelle tout simplement Deburau. (Janin vol. 1, 13-14).

This personification of dramatic art is a portrait, a portrait of the working-class spectator conflated with a portrait of the working-class performer, Deburau; Janin visualizes the art of drama as a character darning his (or her) stockings on the street, eating French fries, getting drunk and wearing flour face make-up (rather than aristocratic, ancien régime face powder). The point of this personification is to attack the theatrical status quo in almost personal terms. Janin does not claim only that Deburau is a great actor, that his flea-pit theatre is a great theatre, that his spectators are connoisseurs of dramatic art, but that they all embody the essence of dramatic art, that other actors and spectators at more salubrious, state-sponsored theatres do not embody the dramatic art. The almost personal attack was well targeted in the sense that Janin's book was almost certainly not read by the working-class spectators at the Funambules; it was likely to have been too expensive. It would have been read by the betteroff spectators who frequented other theatres and who turned the pages of Janin's book out of curiosity to see how 'the other half' lived and produced theatre.

Janin's campaign for the working class and attack on bourgeois theatre puts the "Savetier" portrait in a different light. The future face of theatre is that of one of the lowliest tradesman, the cobbler who repairs shoes (as opposed to the bootmaker who makes them), whose very trade, according to the 1835 Dictionnaire de l'Académie française, is synonymous with inferior workmanship. ${ }^{19}$ Janin sees his role as a modern Plutarch writing the Lives of great men, whatever their social extraction: “Faisons l'histoire de l'art tel qu'il est, crotté, crasseux, mendicant, ivrogne, remuant un Parterre crotté, crasseux, mendicant et ivrogne; puisque Deburau est devenu le Roi de ce monde, célébrons Debureau [sic] le Roi de 
ce monde” (Janin vol. 1, 14-15). Having read the text, the reader looking again at the "Savetier” portrait might interpret the way Deburau holds the gaze of the viewer as bold or even insolent, his contorted mouth as a sneer at theatrical tradition. Thus, text and portrait complement each-other: the text makes the portrait more meaningful, while the portrait gives the ideas in the text a striking visual presence.

\section{Small portraits of a great Pierrot}

After the Preface, the first chapter of Janin’s book begins with a historiated letter ' $\mathrm{j}$ ' which is, in fact, a portrait of Deburau. The tradition of illuminating letters is a long one, and it is given significant new momentum in the nineteenth century by improvements in woodcut techniques and the invention of lithography. As familiar as the reader may have been with such decorated letters, this particular example is unusual. Not only does the figure represent an identifiable person, but the figure is the subject of the book, Deburau. More unusual still, the portrait does not decorate the letter ' $\mathrm{j}$;' it is the letter ' $\mathrm{j}$ ’: the picnic basket forms the tail of the letter, Deburau's body is the stem, while his raised hat is the dot (Figure 3). [Figure 3 near here] At $2.2 \mathrm{~cm} \times 2.2 \mathrm{~cm}$, this is the smallest portrait of Deburau, and an apparently incongruous start to a biography written to extol his greatness. The contrast between diminutive stature and profound greatness is nevertheless the substance of this first chapter of the book. Janin claims that his vocation as cultural critic is to discover and nurture artistic talent, however humble or unassuming it might appear. The miniature size of this portrait is therefore the very point: as small and as unassuming as the mime actor is, as humble as his working-class theatre is, they deserve recognition. Once recognized, the reader may agree with Janin's conclusion at the end of this chapter that Deburau is "le Grand Comédien," capitalized in contrast to his apparent stature in the opening illustration as a miniscule ' $\mathrm{j}$ ' (Janin vol. 1, 23). 
The next portrait comes in Chapter 3. It shows Deburau clinging to the top of a ladder, dressed in the chequered costume of a "Paillasse" rather than Pierrot's white costume, looking down apparently frightened (mouth open, raised eyebrows), drawn by Tony Johannot, engraved by Porret (Figure 4). [Figure 4 near here] Béraldi thinks Deburau’s chequered costume inspired the chequered book cover, marking the beginning of illustrated book covers (Béraldi vol. 8, 268). This image of Deburau looks like a stage scene in which he performs something akin to a standard ladder lazzi, recurrent in Commedia dell'arte theatre and indeed used in Deburau's time at the Théâtre des Funambules. ${ }^{20}$ He is not wearing the Pierrot costume because this illustration is supposed to show him early in his career when he performed more as an acrobat and 'fall-guy' for other characters. Janin's text has a similar function relative to this illustration that it had for the "Savetier" image: it turns something ordinary into something extraordinary. The illustration depicts the moment in Constantinople at the Sultan's palace when Deburau's ladder routine led to the unique and dangerous experience of looking over the curtain into the Sultan's harem. This story prompts Janin to present Deburau as much more than a commonplace paillasse, an ordinary performer of stock stage acrobatics, because the eyes of this mime-actor have witnessed what we can hardly imagine, and what Bouquet cannot represent visually. He has risked his life in the furtherance of his art, but has done so almost by accident; he is an accidental genius, one who is not aware of his own brilliance. This mere "paillasse,” this “vers de terre” was destined for greatness (Janin vol. 1, 47-8).

The first chapter of Volume 2 of Janin's book opens in the same way as Volume 1: with a historiated letter, this time a 'D,' formed from the linked bodies of Pierrot and Arlequin (Figure 5). [Figure 5 near here] The latter's posture is uncharacteristically upright (apart from his head) and symmetrical, forming the stem of the letter, while Deburau's posture is lithe, asymmetric and dynamic, forming the curved bowl of the letter. Any movement that one 
could imagine arising from this duo would most likely have to come from Pierrot. He dominates and dwarfs Arlequin. The advantage Pierrot clearly has over Arlequin is a glimpse of the frequent rivalry between them, and on this occasion, it is Pierrot who has the upper hand. This rivalry is almost as common in Deburau's pantomimes as it was between previous incarnations of the two roles, with the important distinction, however, that Deburau's Pierrot has the upper hand much more often than previous Pierrots did. This is symptomatic of the greater dramaturgical importance that Pierrot acquired when Deburau played him.

The theatrical licenses awarded to the Théâtre des Funambules in 1813 and 1815, the ones which it more or less abided by until the licensing system was greatly relaxed after the Revolution of July 1830, obliged it to stage acrobatics and "pantomimes-arlequinades." ${ }^{21}$ The censors were clear that the latter had, by definition, to be centered around the figure of Arlequin. Despite this, Deburau’s Pierrot came to eclipse Arlequin at least from 1825 when 'Pierrot' figured for the first time in the title of a pantomime-arlequinade at the theatre. ${ }^{22}$ It is this rise to dominance that is reflected in the ' $\mathrm{D}$ ' illustration. Thus, history of performance is reflected in the iconography of this book.

The next portrait, "Le Repas de Pierrot” (Figure 6), seems to have the barest possible relation to the text. There is no 'intracompositional' principle (in Werner Wolf's terms), no mutual integration of text or image, only contiguity. The image is nevertheless one which seemed to appeal, since lithographic copies of it circulated independently of Janin's book. ${ }^{23}$ This is the only illustration that Janin refers to directly in his text, but he does so, paradoxically, in order to point out that it is unconnected to the text. He explains that he cannot publish the scenario of one of Deburau's most famous pantomimes, Le Boeuf enragé, for fear of irritating the anonymous author of the scenario (whom many contemporaries thought was Nodier). He writes that he has left Bouquet to choose and illustrate his favorite scene (Bouquet signs the illustration but the engraver is anonymous). Readers would have 
recognized the "scène de gueule et de gourmandise” as quite typical of Pierrot's voracious appetite (a characteristic associated with Arlequin until Deburau made it Pierrot's). If it was indeed Bouquet's favorite scene, this might explain why he also seems to have used it in the earlier portrait in miniature of Pierrot as the letter ' $\mathrm{j}$,' which looks like a standing version of “Le Repas de Pierrot.”

Janin’s text ends with an engraving which is not a portrait, but a stage representation of Comédie-italienne characters with Pierrot nonetheless occupying a central position (Figure 7). [Figure 7 near here] Janin has made little mention of Pierrot's fellow actors in the rest of the book, despite their obvious importance to the ascendancy he claims for Deburau. This parting image is at least some recognition of them. It is a much more conventional composition than the other illustrations. The musicians in the foreground immediately signal to the reader that this is a theatrical scene, and it is easy to imagine what the posture of each character would suggest they are doing: the kneeling young man asks the old Cassandre for Colombine’s hand in marriage, Colombine remains aloof, Pierrot tries to act as a helpful intercessor, and Arlequin threatens to make mischief, perhaps using his magic bat. This image does, however, have a feature which none of the others have in the book: its timelessness. It could be a scene from a Comédie-italienne or Commedia dell'arte play of any period since the invention of the Pierrot role in the seventeenth century. In the last pages of his book, Janin claims that he is "l'historien du Bas-empire dramatique," comparing himself to the eighteenth-century historian Edward Gibbon (Janin vol. 2, 297). Given Janin’s tendency to hyperbole, what he means by this is probably no more than that he has succeeded in giving historical perspective to a historically important phenomenon. He portrays Deburau as rooted in and indeed maintaining a long historical tradition. Like many of his contemporaries, he reveres the Commedia dell'arte and its cousin the Comédie-italienne as a fountainhead of theatrical creativity which has by dint of its creative energy managed to traverse the 
centuries. ${ }^{24}$ As Janin pens the last words of his book, he imagines that Deburau was doubtless at that very moment performing one of the stock scenari of Italian comedy "pour la dix millième fois au moins” (Janin vol. 2, 302). The engraving supports this vision of the timeless Italian comedy of which Deburau, according to Janin and many of his contemporaries, is the greatest contemporary exponent.

\section{Creating cultural heroes}

Overall, these seven visual and textual images of Deburau are a sign of a particular kind of portrait 'mania' based on a poetic representation of the 'spirit' of Deburau (in Baudelaire's sense of the "esprit” of a portrait) more than verifiable facts. Janin's book is all the more an example of this mania when we consider that its subject, a Pierrot actor, was so humble, even obscure. It was just as extraordinary for Bouquet to exhibit a portrait of a Pierrot at the Salon as it was for Janin to devote a two-volume monograph to him and claim that he and his theatre were the future of drama. No one had painted Deburau's portrait before; he had never been considered important enough to be included in published albums of actors’ portraits. Even though the press was starting to talk about him, and however much of a local following he had among the working class and select intellectuals, he was still relatively obscure. His theatre was not even thought important enough for its nightly bill of pantomimes-arlequinades to be published in the press. Bouquet's reasons for painting Deburau were likely to have been similar to Janin's reasons for writing: barely a year after the July Revolution, they were seeking a new socio-political and artistic vision, a vision which one can equally see manifested in other works exhibited at the 1831 Salon: Eugène Devéria’s Louis Philippe prête serment devant les Chambres, Henry Scheffer's L'Arrestation de Charlotte Corday, and of course Delacroix’s La Liberté guidant le peuple. The collaborative nature of this book and the resultant intermedial relation between the illustrations and the text are a product of the 
prevalent feeling of exhilaration among many intellectuals and artists in the immediate aftermath of the July 1830 Revolution. With the objective of reshaping art and society, Janin and his collaborators sought new cultural heroes, they aimed to demarginalize a working-class actor and elevate him above the established order. The cult of celebrity they promoted around Deburau explains the unusual way they present him. Bouquet's "Pierrot at the balustrade" is unlike any other portrait of its time; it is more akin to the many studio photographs taken of Sarah Bernhardt throughout her career in costume and on stage, not acting but returning the viewer’s gaze, connoting without denoting her theatrical roles. ${ }^{25}$ It has the same psychological intensity.

Janin's text would make its point even without the illustrations, and Bouquet's illustrations in particular had a life and circulation of their own before and after the book was published. In a sense, then, the text and the illustrations were relatively independent of each other. Hence, even though the text dominates in sheer terms of coverage (300 pages and a total of eight images), the illustrations have a potential to be relatively autonomous; they are not crudely derivative or dependent on the text. The semiotic relationship is balanced in the sense that the text promotes an interpretation of the image, but the image also encapsulates effectively the sense of the text. Once the text has invested the image with meaning, the image will keep its meaning for most readers. It is indeed Pierrot's image that has been passed on to posterity (to an astonishing degree) rather than Janin's text. Both, however, are examples of 'portraitomanie.' The importance Janin attributes to the individual genius of the artist, the value he places in biography as a means to understand art, and the priority he gives to his own subjective intuitions as a critic to understand art and artist, all these characteristics of his approach are strongly reminiscent of Sainte-Beuve’s principles in his Portraits littéraires. 'Portraitomanie,' then, is a literary phenomenon as much as a pictorial one, so an illustrated book like Janin's is a particularly good way to understand the phenomenon. 
${ }^{1}$ The best general history of the Pierrot role (in France) is Robert F. Storey, Pierrot. A Critical History of a Mask (Princeton: Princeton U P, 1978).

${ }^{2}$ Deburau first performed the Pierrot role in 1816 in Arlequin chef des brigands; the manuscript scenario (written by Martial) gives his name in the cast list and is archived in the library of the Société des auteurs et compositeurs dramatiques (henceforth S.A.C.D.), Paris. Existing scholarship usually gives erroneous dates; Louis Péricaud specifies 1819 in Le Théâtre des Funambules: Ses mimes, ses acteurs et ses pantomimes depuis sa fondation jusqu’à sa démolition (Paris: Léon Sapin, 1897), 20, and Storey gives 1925 (95). ${ }^{3}$ Anon., “Théâtre des Funambules,” in Le Figaro (27 June 1828): 3; Charles Nodier, “M. Debureau,” in La Pandore (19 July 1828): 2; Anon., “Théâtre des Nouveautés,” in Le Grondeur (13 and 14 June 1829): 3; Anon., “Théâtre des Funambules,” in Le Compilateur. Revue de la semaine, esprit des journaux (27 September 1829): 48-9.

${ }^{4}$ The only publication in Deburau's lifetime to contain more portraits and images of him is Cham, ed., Musée ou magasin comique de Philipon, vol. 23 (с. 1842), 177-84.

${ }^{5}$ For Bouquet's exhibited oil portrait, see Explication des ouvrages de peinture, sculpture, gravure, lithographie et architecture des artistes vivans, exposés au Musée royal le 1er Mai 1831 (Paris: Vinchon, 1831), in which entry number 217 is “Bouquet (A.), Portrait de M. J. Deburau." See also the description by Auguste Jal, Salon de 1831. Ebauches critiques (Paris: A.-J. Dénain, 1831), 177-81. With regard to subsequent copies, the first was published in L'Artiste, 2 (1831), between pages 112 and 113 (black-and-white lithography by Delaunois). Hélène (“Arsène’) Trouvé exhibited a miniature copy, oil on ceramic, bearing the date “1832” at the Paris Salon of 1835. Janin refers to this version (by "Mlle Arsène Trouvé") in Deburau, vol. 2, 153, and it is currently exhibited in the Musée Carnavalet in Paris. Another lithographic version was produced by A. Veuly and Bernard de Frey. Achille Devéria’s 
portrait of Bouquet shows him in the process of painting Deburau's portrait, thus suggesting the degree to which Bouquet was associated with "Pierrot at the balustrade," and probably also suggesting that it was a well-known image; see the frontispiece to Champfleury, Le Peintre ordinaire de Jean-Gaspard Deburau (Paris: Imprimerie de l’art, 1889). Champfleury does not name the artist, but the similarity with other portraits by Devéria is unmistakable, and this is the attribution in Raoul Deberdt, La Caricature et l'humour français au 19e siècle (Paris: Larousse, 1898), 128.

${ }^{6}$ On the distinction between portraits of the private person and of the theatrical role, see Maria Ines Aliverti, “Major Portraits and Minor Series in Eighteenth-Century Theatrical Portraiture,” Theatre Research International, 22.3 (1997): 235.

${ }^{7}$ See for example Galerie des artistes dramatiques de Paris, 3 vols. in 2 (Paris: Marchant, 1841).

${ }^{8}$ See for example the lithography of a contemporary of Deburau's, Mazurier, Artiste de la Porte St. Martin, by Dubouloz and Cardon, showing an oval portrait of the actor in everyday dress, below which there is a scene from one of his plays, "14e scène de Polichinel vampire." ${ }^{9}$ Frédérick Lemaître became famous for his intentional over-acting and frequent remarks to the audience in the performance of a melodrama intended by the playwrights to be serious, L'Auberge des Adrets (first performed at the Théâtre de l’Ambigu-comique, 2 July 1823). ${ }^{10}$ Champfleury describes a moment when Deburau responded to the audience in Souvenirs des Funambules (Paris: Michel Lévy Frères, 1859), 12, but he seems to present it as an exceptional case, provoked by an expression of sympathy from the audience for the terminally ill Deburau. Banville remarks that Deburau’s Pierrot has a certain detachment from the action, see “Les Petits Théâtres de Paris” in Musée des familles; lectures du soir, 84 vols. (Paris, 1833-1900), vol. 13 (1845-6): 238, but contemporaries more often commented on Deburau’s energetic engagement with the plot. 
${ }^{11}$ The best published collection of Commedia dell'arte iconography, Cesare Molinari's $L a$ Commedia dell'arte (Milan: Mondadori, 1985) contains no portraits like Bouquet's.

${ }^{12}$ See Baudelaire’s distinction between portraiture as "l’histoire” and as "roman” in "Du Portrait,” Salon de 1846, Euvres complètes, 2 vols (Paris: Gallimard, 1976), vol. 1, 464. 13 Tristan Rémy, Jean-Gaspard Deburau (Paris: L’Arche, 1954), 218.

${ }^{14}$ The expression is used by Norman Bryson to characterize the impression made by Watteau's paintings on many contemporary viewers, Word and Image: French Painting of the Ancien Régime (Cambridge: Cambridge U P, 1982), 74.

${ }^{15}$ On the Romantic interpretation of Watteau’s Pierrot, see Francis Haskell, “The Sad Clown: Some Notes on a Nineteenth-Century Myth,” in French Nineteenth-Century Art and Literature, ed. Ulrich Finke (Manchester: Manchester U P, 1972). For a detailed account of the eighteenth- and nineteenth-century reception of this painting and others by Watteau, see Judy Sund, “Why so Sad? Watteau’s Pierrots,” The Art Bulletin, 98.3 (2016): 321-47 who points out that in the nineteenth century, Watteau's Pierrot was exhibited for the first time in decades in December 1846. She suggests that Deburau's death 5 months earlier was a motivating factor.

${ }^{16}$ See Doris Panofsky, “Gilles or Pierrot,” in Gazette des beaux-arts, 39 (1952): 319.

${ }^{17}$ Champfleury claims that Bouquet subsequently produced a larger version of this image in oils (Le Peintre ordinaire, 11).

${ }^{18}$ According to Banville, Bouquet's “Savetier” is inspired by Deburau’s role as a cobbler in the pantomime that he calls Le Diable à quatre, whose title is in fact Le Lutin femelle, (it is a version of Sedaine’s opéra comique Le Diable à quatre), performed some time in 1832. See Théodore de Banville, “Les Petits Théâtres de Paris”, 238; see also Péricaud 109.

19 “Savetier: C'est un savetier, ce n'est qu'un savetier, se dit d'un mauvais ouvrier en quelque métier que ce soit.” See Dictionnaire de l'Académie française, 6th edition (Paris: Firmin 
Didot frères, 1835). English 'cobbler' had the same connotation in this period; see "cobbler, n.”. OED Online. December 2018. Oxford University Press.

http://www.oed.com/view/Entry/35218?redirectedFrom=cobbler (accessed December 04, 2018).

${ }^{20}$ For Commedia dell'arte lazzi, see “Lazzi della scala” in Nicoletta Capozza, Tutti i lazzi della commedia dell'arte; Un catalogo ragionato del patrimonio comici (Rome: Dino Audino, 2006). For Deburau's comic, acrobatic use of ladders, see for example scene 13 of Jean Toussaint Gougibus, Les Capucins aux frontières, pantomime comique à spectacle, combats etc, performed at the Funambules, 9 Novembre 1830, m.s., S.A.C.D., Paris.

${ }^{21}$ For more detail of the repertoire and its legal restrictions, see my article, “The Pantomime Repertoire of the Théâtre des Funambules,” Nineteenth-Century Theatre and Film, 43:1 (2016): 3-20.

${ }^{22}$ See the first pantomime-arlequinade at the Théâtre des Funambules with a title including the name "Pierrot": Le Pirate sicilien, ou Pierrot libérateur, first performed 11 November 1825, m.s., S.A.C.D., Paris. The manuscript scenario bears the censor’s comments (JacquesAndré Jacquelin) to the effect that this work contains too little of Arlequin and too much of Pierrot for a theatre limited to staging pantomimes-arlequinades. This is the year when Deburau takes over the Pierrot role completely from Charigny (Charigny’s name no longer appears in any scenari, and Pierrot is consistently listed as played by Deburau).

${ }^{23}$ This image was first published in La Revue des peintres, copies de tableaux, aquarelles et dessins des artistes modernes, accompagnées de note explicative et biographique (Paris: Chez Aubert, 1834), Plate 51. Champfleury claims that it is an engraving of a painting bought by Etienne Arago which has now disappeared, and he lists another lithographic version in addition to that published in La Revue des peintres; see Champfleury, Le Peintre ordinaire, 42-3. 
${ }^{24}$ See, for example, Maurice Sand, Masques et bouffons (Comédie italienne). Texte et dessins, 2 vols (Paris: Michel Lévy, 1860), especially the Préface, written by George Sand, and the Avant-propos.

${ }^{25}$ See Heather McPherson, The Modern Portrait in Nineteenth-century France (Cambridge: Cambridge U P, 2001), Ch. 3. 